А. В. Федоров, В. В. Чалий, В. П. Фінаєв

Харківський національний університет Повітряних Сил імені Івана Кожедуба, Харків, Україна

\title{
ВИКОРИСТАННЯ СИСТЕМИ МУЛЬТИЛАТЕРАЦІЇ ДЛЯ ПІДВИЩЕННЯ ЯКОСТІ РАДІОЛОКАЦІЙНОГО КОНТРОЛЮ ПОВІТРЯНОГО ПРОСТОРУ
}

\begin{abstract}
Предметом вивчення в статті є система мультилатерації (MLAT) та ії взаємодія з існуючими засобами радіолокації під час ведення радіолокаційного контролю (РЛК) повітряного простору. Метою $є$ аналіз можливостей використання системи MLAT для підвищення ефективності РЛК повітряного простору. Завдання: аналіз основних тенденцій розвитку засобів повітряного нападу, аналіз відомих організаційних та технічних шляхів підвищення ефективності ведення РЛК малопомітних та малорозмірних повітряних об’єктів (ПО), визначення напрямків поєднання можливостей системи MLAT та інформації від існуючих радіолокаційних засобів, аналіз можливості отримання інформації від системи MLAT в радіотехнічних підрозділах, аналіз особливостей та обмежень на використання інформації від системи MLAT. Використовуваними методами $є$ : методи визначення координат ПО, різницеводалекомірний метод, методи пасивної радіолокації, методи визначення координат ПО з використанням інформації супутникових навігаційних систем. Отримані такі результати. Встановлено, що система MLAT є системою незалежного кооперативного спостереження, в основі роботи системи MLAT покладений відомий далекомірний метод визначення координат ПО, мінімальна кількість пунктів прийому дорівнює трьом, отримано вираз для лінійної похибки різницево-далекомірного методу в системі MLAT, встановлено, що у якості приймачів в системі MLAT можливе використання транспондерів системи ADS-B, наведено декілька варіантів рішення задачі по виявленню потенційно небезпечних ПО, що бажають бути непоміченими, або здійснюють “мімікрію”. Висновки. Наукова новизна отриманих результатів полягає в наступному: підвищення точності визначення координат ПО та якості РЛК повітряного простору шляхом поєднання можливостей системи MLAT та інформації від існуючих радіолокаційних засобів; встановлено, що використання системи MLAT суттєво підвищить точність супроводження ПО; намічені шляхи оптимізації геометричної побудови приймачів системи MLAT на позиціях радіотехнічних підрозділів та розробки методу сумісної обробки радіолокаційної інформації та інформації від системи MLAT при РЛК повітряного простору.
\end{abstract}

Ключов і слов а : радіолокаційна станція, мультилатерація, MLAT, джерела інформації, повітряна обстановка, залежне спостереження, незалежне спостереження, контроль повітряного простору, координати.

\section{Вступ}

Постановка проблеми у загальному вигляді. Досвід ведення сучасних мережецентричних, гібридних війн, ведення антитерористичної операції та операції об'єднаних сил (ООС) на сході України свідчить про те, що на даний час розвиток засобів повітряного нападу (ЗПН) проходить за рахунок використання сучасних технологій та відбувається досить стрімко $[1,2]$.

Відомо [1-4], що історія розвитку засобів збройної боротьби проходить у постійному технічному протиборстві ЗПН та засобів захисту. У відповідь на удосконалення засобів нападу з'являються більш удосконалені засоби захисту. Використання високих технологій у сучасній війні $є$ запорукою успішного ведення бойових дій.

Основні тенденції розвитку ЗПН на сучасному етапі обумовлені впровадженням сучасних технологій та полягають у наступному [1, 3-5]:

- покращення льотно-тактичних характеристик;

- зменшення радіолокаційної помітності;

- вдосконалення бортового радіоелектронного обладнання та вогневих засобів;

- впровадження безпілотного управління та новітніх інформаційних технологій.

Отже, основні тенденції розвитку ЗПН спрямовані на реалізацію концепції адаптивних розвідувально-ударних бойових систем, яка відповідає вимогам безконтактних війн, форми, способи та структура яких можуть створюватися та уточнюватися у реальному масштабі часу в залежності від обстановки.

Розвиток ЗПН та впровадження перспективних методів ведення бойових дій в єдиному інформаційному просторі зумовлює необхідність розвитку систем виявлення та визначення координат повітряних об'єктів (ПО). Військові конфлікти останніх років показали, що активні первинні радіолокаційні станції (РЛС) залишаються основним джерелом інформації про повітряну обстановку $[2,5]$.

Створення і підтримка суцільного радіолокаційного поля (РЛП) на малих, середніх та великих висотах залишається важливим завданням радіотехнічних військ (РТВ) Повітряних Сил (ПС) Збройних Сил України (ЗСУ). Від якості РЛП, що створюється, залежить успішність виконання завдань 3 ведення радіолокаційного контролю (РЛК) повітряного простору. У теперішній час виконання цього завдання ускладнюється внаслідок зменшення радіолокаційної помітності сучасних ЗПН.

РЛК ведеться за допомогою засобів радіолокації, які знаходяться на озброєнні РТВ ПС ЗСУ. До засобів радіолокації належать РЛС та радіолокаційні комплекси, які за призначенням поділяться на РЛС (радіолокаційні комплекси) бойового та чергового режимів [3].

Основними РЛС чергового режиму в радіотехнічних підрозділах є РЛС 5Н84А та модернізована РЛС 5Н84МА, РЛС П-18 та пї модифікації РЛС П-18МУ, РЛС П-18МА, РЛС П-18 «Малахіт». Основними РЛС бойового режиму в радіотехнічних 
підрозділах є РЛС 19Ж6, РЛС 35Д6 та модернізована РЛС 35Д6М, РЛС П-37 (П-37Р), РЛС 79К6 [6-8].

За результатами аналізу тактико-технічних характеристик (ТTX) засобів радіолокації радіотехнічних підрозділів ПС ЗСУ [9] встановлено, що вони були розраховані на виявлення повітряних цілей типу винищувача МіГ-21 (МіГ-29). Тому, при виявленні сучасних та перспективних малопомітних та малорозмірних ЗПН спостерігається погіршення можливостей РЛС, які знаходяться на озброєнні РТВ. Зменшення розмірів зон виявлення окремих РЛС приводить до порушення суцільності РЛП і утворенню розривів, які можуть досягати до 80\% від потрібного розміру суцільного РЛП.

Найбільш суттєве зменшення зони виявлення РЛС спостерігається в сантиметровому діапазоні, а найменше - в метровому діапазоні. Це зумовлено особливостями відбиття радіохвиль від малорозмірних об'єктів та зменшенням ефективності використання технологій Stealth в метровому діапазоні.

Система РЛК повітряного простору повинна забезпечити вирішення наступних задач [6]:

- безперервність РЛК;

- забезпечення поточною інформацією про повітряну обстановку органів державного та військового управління у мирний та воєнний час;

- своєчасне попередження про повітряний напад;

- забезпечення видачі радіолокаційної інформації 3 необхідною дискретністю, мінімальним часом запізнювання на військові пункти управління для оцінки повітряної обстановки, вирішення завдань цілерозподілу та управління військами, вогневими засобами, засобами радіоелектронної боротьби;

- інформаційну підтримку бойових дій усіх видів авіації;

- забезпечення контролю законності та порядку використання повітряного простору, виявлення ПО, які представляють собою потенційну загрозу державі або іншим учасникам повітряного руху;

- забезпечення контролю порядку перетинання державного кордону;

- забезпечення безпеки польотів авіації, управління повітряним рухом, радіолокаційне забезпечення польотів та перельотів авіації, запобігання конфліктних ситуацій у повітрі та ін.

Для вирішення покладених завдань просторові показники бойових можливостей системи РЛК повинні у повній мірі забезпечувати виявлення та супроводження ПО в усьому діапазоні можливих висот та швидкостей їх польоту. Водночас, існуюча система РЛК не здатна в повної мірі забезпечити вирішення покладених завдань при застосуванні нових типів малопомітних та малорозмірних ЗПН.

Все це призводить до необхідності розробки організаційних та технічних методів підвищення ефективності виявлення малопомітних ПО.

Аналіз останніх досліджень і публікацій. Традиційними (відомими) організаційними та технічними шляхами підвищення ефективності ведення РЛК малопомітних та малорозмірних ПО $є[4,5]$ :
- підвищення енергетичного потенціалу та покращення ТТХ РЛС;

- ущільнення розташування РЛС на небезпечних напрямках (створення смуг виявлення маловисотних та малорозмірних цілей);

- одночасне використання РЛС різних діапазонів частот та інші.

Використання традиційних методів підвищення ефективності ведення РЛК малопомітних та малорозмірних ПО приводить до збільшення потрібної кількості РЛС, збільшенню споживаної потужності та, як наслідок, до збільшення вартості створення та утримання чергового РЛП. Вирішення протиріччя між тенденціями зменшення радіолокаційної помітності ЗПН та можливостями існуючих РЛС щодо їх виявлення потребує розробки нових альтернативних та нетрадиційних методів підвищення ефективності виявлення малопомітних ПО.

Альтернативними (перспективними) шляхами підвищення ефективності виявлення малопомітних та малорозмірних ПО є [8]:

- використання енергій сторонніх джерел випромінювання та реалізації режимів рознесеного прийому;

- використання властивості резонансного відбиття електромагнітних хвиль від ПО при використанні довжин хвиль, які порівняні із розмірами об'єкта;

- використання властивостей бістатичної ефективної площі розсіювання (ЕПР) при рознесеному прийомі.

Використання багатопозиційних радіолокаційних систем у порівнянні з однопозиційними РЛС разом $з$ певними недоліками мають ряд переваг:

- підвищення живучості системи за рахунок просторового рознесення приймальних і передавальних позицій;

- можливість формування і динамічного керування необхідною зоною відповідальності, враховуючи сигнально-завадову обстановку, що очікується, i, що складається;

- можливість підвищення точності вимірювання просторових координат ПО за рахунок використання далекомірних методів;

- підвищення надійності за рахунок надлишкового числа приймальних і передавальних позицій та інші.

В якості передавача в багатопозиційній РЛС може використовуватися як спеціальний (з характеристиками класичного локатора), так і нетрадиційний (зовнішній) передавач, що не входить до складу системи. При такій побудові системи забезпечується приховане РЛП та мінімальні енергетичні витрати на функціонування системи.

Одним із варіантів підвищення ефективності ведення РЛК є використання інформації про повітряну обстановку від різнорідних джерел на пунктах управління РТВ. Це може в цілому підвищити ефективність вирішення завдань в системі контролю повітряного простору.

На теперішній час вже існують радіолокаційні системи, які здійснюють виявлення ПО в полі під- 
свічування сторонніх джерел радіовипромінювання та використовують властивості бістатичної ЕПР ПО. В якості таких джерел використовуються передавачі системи телерадіомовлення, стільникового зв'язку та інші [9].

Для підвищення ефективності РЛК повітряного простору використовуються системи мультилатерації (MLAT). Існує значний обсяг літератури з технічним описом системи MLAT, iї характеристик, переваг та недоліків, можливостей їі використання для контрою повітряного простору $[1,10]$.

В той же час, дослідження стосовно використання цієї систем в інтересах РТВ не проводилися.

Мета статті - аналіз можливостей використання системи MLAT для підвищення ефективності проведення РЛК повітряного простору.

\section{Постановка задачі та викладення матеріалів дослідження}

Основними тенденціями розвитку сучасних засобів повітряного нападу щодо зменшення їх радіолокаційної помітності є:

- зменшення геометричних розмірів, що обумовлює зниження ЕПР;

- реалізація можливості зменшення швидкості польоту, що обумовлює режекцію ЗПН в системах селекції рухомих цілей разом з відбиттями від місцевих предметів;

- використання технологій Stealth, що обумовлює зниження значення моностатичної ЕПР;

- використання композитних матеріалів,що обумовлює зниження ЕПР до величин (0,005-0,1 м²);

- застосування малопотужних економічних двигунів, що робить політ безпілотного літального апаратупрактично безшумним;

- зменшення вартості розробки та експлуатації безпілотний літальний апарат у порівнянні $з$ вартістю сучасних пілотованих засобів, що виконують аналогічні функції.

Це приводить до погіршення ефективності виявлення ЗПН в оглядових РЛС, які знаходяться на озброєнні РТВ ПС ЗСУ, що обумовлюється малими значеннями ЕПР ПО (0,005-0,3 м²).

На період до 2025 року основними об'єктами радіолокації для РТВ ПС є аеродинамічні цілі:

3 очікуваним значенням ЕПР від 0,005 до 10 м², швидкістю польоту від $10 \mathrm{~m} / \mathrm{c}$ до $1200 \mathrm{M} / \mathrm{c}$;

діапазоном висот - від 20 до 30000 м.

Зменшення ЕПР ПО приводить до зменшення потенціальної дальності їх виявлення. Ця залежність визначається виразом (1):

$$
D_{2}=D_{1} \sqrt[4]{\frac{\sigma_{2}}{\sigma_{1}}},
$$

де $D_{1}$ - дальність виявлення ПО

$D_{2}$ - дальність виявлення ПО 3 ЕПР $\sigma_{2}$.

Одним із варіантів підвищення ефективності ведення РЛК є використання інформації про повітряну обстановку від різнорідних джерел на пунктах управління РТВ. Це може в цілому підвищити ефек- тивність вирішення завдань в системі РЛК повітряного простору.

У якості різнорідного джерела у статті розглядається система мультилатерації [15].

Системи MLAT відносять до систем незалежного кооперативного спостереження. Незалежність системи означає, що система не залежить від даних навігаційних система ПС, кооперативність - цю інформацію можуть отримувати як наземні станції підрозділів керування повітряним рухом так і ПО.

Система представляє собою сукупність ідентичних приймачів, які розташовані визначеним чином. В основу роботи системи покладений відомий різницеве-далекомірний метод визначення координат повітряного об'єкта.

Мультилатерація або гіперболічне позиціонування - процес визначення положення, заснований на різниці в часі прибуття (Time Difference of Arrival (TDOA)) сигналу, випромінюваного об'єктом в напрямку трьох або більше приймачів.

Надісланий об'єктом сигнал буде отриманий двома далеко розташованими один від одного датчиками в різний час, це залежить від відстані між датчиком і об'єктом. Різниця в часі між двома приймачами зпівставляється 3 гіперболоїдом (в тримірному просторі), на якому знаходиться ПО.

В основі роботи різницево-далекомірного методу покладено вимірювання відносної затримки сигналів, які приймаються в трьох пунктах прийому, та визначенні лінії переміщення (ЛП) (гіпербол), а також вирахування координат точки перетину ЛП. Нехай пункти прийому знаходяться в рознесених точках спостереження A1, A2, А3, ПО - в точці М. Відстані між точками А1, A2, А3 позначені відповідно d12, d23, відстані від пунктів прийому до ПО позначені D1, D2, D3.

Фокуси гіпербол співпадають 3 точками спостереження (рис. 1).

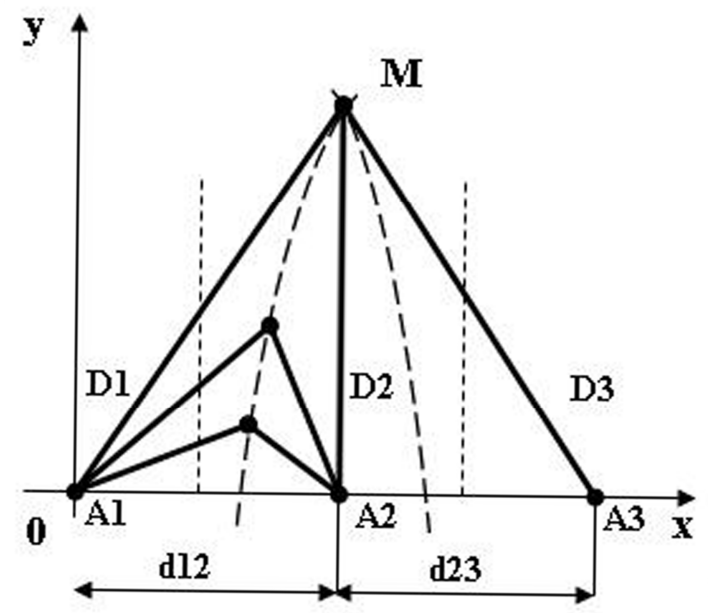

Рис. 1. Різницеве-далекомірний метод визначення положення ПО

Різниці відстаней визначаються шляхом виміру відносного запізнення сигналів між пунктами прийому та позначаються: $P_{12}=$ const $=D_{1}-D_{2}$ та $P_{23}=$ const $=D_{2}-D_{3}$. 
Просторове положення ПО визначається по трьом різницям дальностей, які були виміряні в приймальних пунктах.

Координати ПО визначаються як точка перетину гіперболоїдів обертання. зом (2):

Лінійна похибка методу визначається за вира-

$$
\sigma_{Л}\left(D_{1}-D_{2}\right)=\frac{\sigma\left(D_{1}-D_{2}\right)}{2 \sin \phi},
$$

де $\sigma$ - середньоквадратичне відхилення визначення $P_{12}$;

$\phi$ - кут $A_{1} M A_{2}$.

Зазвичай бази $\mathrm{d} 12$ та d23 розташовуються не на одній лінії, а під кутом, що складає від 60 до 90.

В якості приймачів системи MLAT пропонується використовувати транспондери ADS-B.

Слід зазначити, що не всі, навіть сучасні ПО, обладнані подібною апаратурою [16]. Наприклад, більшість літаків "Embraer" не обладнані такими транспондерами. Також не обладнані літаки "Mcdonnell douglas MD-83", що використовуються однією з українських авіакомпаній. Більшість літаків, що виготовлені за радянських часів, не мають такого обладнання. Але зараз практично всі сучасні ПО мають спроможність роботи в режимі «S» системи вторинної локації RBS. В режимі вторинної локації сучасні ПО відповідають на сигнали запитів трасових локаторів УПР. Відповідь здійснюється на тій же частоті, що і ADS-B, а саме 1090 МГц. Відповідно приймач ADS-B здатен приймати і сигнали відповідей ПО на запити трасових локаторів. А так як сучасні повітряні судна практично завжди здійснюють політ в полі трасових локаторів, то практично завжди присутні сигнали відповідей. Аналізуючи ці сигнали, можна отримати ті ж самі дані, що від ADS-B, за винятком поточних координат. Так, використовуючи дані цих сигналів, можна отримати інформацію про адресу ICAO, висоту, SQUAWK, позивний. Для визначення координат ПО, що не передає своїх координат можна використовувати технологію MLAT.

Для використання різницеве-далекомірного багатопозиційного способу виявлення координат потрібно обробляти сигнали щонайменше від трьох приймачів, маючих просторовий рознос та точну синхронізацію часу. Точна прив'язка часу (до 50 нс) може здійснюватися за допомогою GPS приймачів.

Технологію MLAT використовує широко відомий Інтернет ресурс "FlightRadar", де здійснюється обробка сигналів від тисяч ADS-B приймачів.

Під час ведення радіолокаційного контролю повітряного простору, за умови сумісного використання технології MLAT та вже існуючих засобів радіолокації задача дещо може бути спрощена. При організації взаємодії з органами управління повітряним рухом (УПР) та отримання від них радіолокаційної інформації від вторинних локаторів, що працюють в режимах “А” та “C” RBS присутня інформація про висоту ПО та код SQUAWK. Згідно з правилами виконання польотів в зоні дії трасового ло- катора коди SQUAWK не повинні повторюватися (за виключенням спеціальних 2000, 7000, 7500, $7600,7700)$ [16]. Таким чином, по коду SQUAWK можна ототожнити дані про координати ПС від вторинного локатору та дані режиму “S” RBS від приймача ADS-B.

\section{Особливості та обмеження використання системи MLAT}

Враховуючи технічні характеристики приймачів ADS-B, є можливість отримання додаткової інформації про ПО та підвищення точності їх супроводу [16].

А, враховуючи максимальну дальність дії, що складає приблизно 400 км, можна отримувати дані від ПО, що не входять у повітряний простір України i відповідно про які нема відомостей у органах управління повітряним рухом України. Тобто 3'являється можливість отримувати дані про ПО, що здійснюють польоти вздовж кордону України, не перетинаючи його.

Однак для забезпечення отримання якомога точних координат ПО, що не входять у повітряний простір України, використовуючи технологію MLAT, необхідно забезпечити оптимальне геометричне розміщення приймачів системи.

Крім того приймачі повинні розташовуватися на достатньо великій відстані один від одного, в іншому випадку точність визначення координат ПО на великій відстані може бути визначена 3 великою похибкою.

Таким чином, використовуючи принцип технології MLAT можна розмістити по одному приймачу ADS-B на позиціях окремих мобільних радіотехнічних підрозділів, таким чином створивши необхідну геометрію розташування приймачів в системі MLAT для більш якісного обчислення координат ПО в необхідній зоні.

Але не слід забувати і про те, що використовуючи дані від приймачів ADS-B, слід бути обережними, оскільки противник може свідомо створювати ці дані $з$ метою організації провокаційних дій. Існує декілька прикладів введення спотворених даних про ПО [16].

По-перше, можна виготовити радіопередавальний пристрій, що буде випромінювати сигналі від реально не існуючих ПО. У цьому випадку технологія MLAT $є$ одним з найбільш ефективних способів боротьби з порушеннями подібного роду. MLAT дозволяє визначити координати розташування такого передавача. Додатково, використовуючи дані приймачів ADS-B, є можливість порівняти дані ADS-B 3 даними, що отримуються від радіолокаційних засобів для виявлення таких «віртуальних» цілей.

По-друге, ще одним способом спотворення може бути підміна координат в повідомленнях ADS-B. Більш того, такі спотворення можуть надходити від законослухняних користувачів повітряного простору. Наприклад, якщо супутниковій навігаційній системі літака поставити відповідні завади [16]. Виявлення таких спотворень здійсню- 
ється також порівнянням 3 радіолокаційними даними або застосування технології MLAT.

По-третє, противник може підмінити в повідомленнях адреси ICAO ПО. Наприклад, літакрозвідник "мімікрує” під реально існуючий пасажирський літак Boeing-737, данні про який присутні в базі даних. Виявити таку підміну шляхом порівняння з радіолокаційними даними або використання технології MLAT неможливо.

Проте існує декілька варіантів рішення здачі по виявленню таких потенційно небезпечних ПО.

По-перше, від органів УПР потрібно постійно отримувати дані по запланованим перельотам і перевіряти цю інформацію 3 поточними даними про повітряну обстановку. Однак, у цьому випадку є можливість оперувати лише даними про ПО, що здійснюють політ тільки у межах повітряного простору України.

По-друге, існує вірогідність того, що ПО під яке здійснюється “мімікрія”, саме в даний час виконує політ. Тоді, в різних точках повітряного простору будуть спостерігатися два, або навіть більше ПО 3 однаковим номером ICAО. Наявність такої ситуації свідчить про факт підміни.

По-трете, законослухняний ПО використовує ADS-B протягом всього польоту. ПО порушник буде використовувати підміну тільки на деяких ділянках польоту.

Таким чином, законослухняний ПО, що здійснює переліт, буде виявлятися на максимальній дальності виявлення приймача для висоти польоту ПО. Відповідно, якщо в системі ADS-В виявляється ПО всередині зони дії приймача на великій висоті польоту (тобто ПО не здійснює зліт з аеродрому), то це може свідчити про можливе спотворення даних ADS-B [16].

\section{Висновки і напрямки подальших досліджень}

В роботі основна увага приділена системі незалежного кооперативного спостереження MLAT. Розглянуті можливості отримання даних від системи MLAT в радіотехнічних підрозділах. У якості приймачів системи мультилатерації запропоновано використання приймачів системи ADS-B. Показано, що за рахунок цих даних можна отримати додаткову інформацію стосовно типів ПО, що супроводжуються, їх позивні та рейси (для рейсових літаків). Встановлено, що використання системи MLAT суттєво підвищить точність супроводження ПО. Також наведені деякі обмеження на використання цих даних у радіотехнічних підрозділах.

В подальших дослідженнях необхідно вирішення наступних задач:

- оптимізація геометричної побудови системи приймачів MLAT на позиціях радіотехнічних підрозділів;

- розробка методу сумісної обробки радіолокаційної інформації та інформації від системи MLAT при веденні РЛК.

\section{СПИСОК ЛІТЕРАТУРИ}

1. Артеменко А. М., Пєвцов Г. В. Тенденції розвитку Повітряних Сил Збройних Сил України на основі аналізу досвіду проведення АТО. Новітні технології - для захисту повітряного простору: Тези допов. 11 наук. конф. Харк. ун-ту Повітряних Сил ім. Івана Кожедуба (Харків 8-9 квіт. 2015). Х.: ХУПС, 2015. - С. 16.

2. Савин Л. В. Сетецентрическая и сетевая война. Введение в концепцию. М.: Евразийское движение, 2011. - С. 130.

3. Довідник учасника АТО: озброєння і військова техніка Збройних Сил Російської Федерації / А. М. Алімпієв, Г. В. Пєвцов, Д. А. Гриб. Х.: Оригінал, 2015. - С. 732.

4. Информационный сборник «Особенности боевого применения высокоточных средств поражения и способы повышения эффективности борьбы с ними»: Кибалко И.П., Черный Ю.Н. (ред.). Минск: 1034 ЦВИиИ, 2008. - С. 102.

5. Романченко І.С., Загорка О.М., Бутенко С.Г., Дейнега О.В. Теорія і практика боротьби з малорозмірними низьколітними цілями (оцінка можливостей, тенденції розвитку засобів протиповітряної оборони): монографія. Житомир: Полісся, 2011. - С. 344.

6. Вишневський С.Д., Бейліс Л.В. Погляди на розвиток радіотехнічних військ Повітряних Сил Збройних Сил України. Новітні технології - для захисту повітряного простору: Тези допов. 11 наук. конф. Харк. ун-ту Повітряних Сил ім. Івана Кожедуба (Харків 8-9 квіт. 2015). Х.: ХУПС, 2015. - С. 15.

7. Бєлавін О.В. Погляди на розвиток озброєння та військової техніки радіотехнічних військ Повітряних Сил Збройних Сил України. Новітні технології - для захисту повітряного простору: Тези допов. 13 наук. конф. Харк. нац. ун-ту Повітряних Сил ім. Івана Кожедуба (Харків 12-13 квіт. 2017). Х.: ХУПС, 2017. - С. 18-19.

8. Образцов Е.А., Пушков О.В. Маловысотные РЛС: шаг за шагом. Воздушно-космическая оборона. 2012. № 4. С. 17-22.

9. Griffiths H. D. From a Different Perspective: Principles, Practice and Potential of Bistatic Radar. International Conference on Radar. (Adelaide, Australia, 3-5 September 2003). Adelaide, 2003. - P. 1-7.

10. Аналіз ефективності використання системи mlat в аеропортах для контролю повітряного простору / А. В. Федоров, Д. В. Головняк, В. А. Андрієвський, С. І. Куцмус, Ю. Ю. Галаговець // Системи управління, навігації та зв'язку : Науковий журнал. №2 (48). - Полтава, 2018. - С. 30-33.

11. Львова Л.А. Радиолокационная заметность летательных аппаратов. Снежинск: Изд-во РФЯЦ - ВНИИТФ, 2003. C. 232.

12. Ягольников С., Нестеров С., Ковалев С. И др. Видимость "невидимок". Воздушно-космическая оборона. 2007. №3 (34) . - C. 24-32.

13. Масалов С.А., Рыжак А.В., Сухаревский О.И., Шкиль В.М. Физические основы диапазонных технологий типа «Стелс». Санкт-Петербург: ВИКУ им. А.Ф.Можайского, 1999. - С. 163.

14. Чепурний В.А., Бардаков М.В., Худов Г.В. Аналіз тенденцій розвитку та застосування розвідувальних безпілотних апаратів в сучасних мережецентричних та гібридних війнах. Наука і техніка Повітряних Сил Збройних Сил України. 2015. № 4 (21). - C. 24-28. 
15. Мультилатераційні системи спостереження повітряного руху. Навчальний посібник. Під загальною редакцією Яковлєва О.І. - К.: ДПОПР України. - С. 2010-192.

16. С.П. Лещенко. Використання інформації ADS-B в інтересах підвищення якості ведення радіолокаційної розвідки повітряного простору // С.П. Лещенко, О.М. Колесник, С.А. Грицаєнко , С.І. Бурковський // Наука і техніка Повітряних Сил Збройних Сил України. - Х.: ХНУПС, 2017. - Вип. № 3(28). - С. 69-75.

Рецензент: д-р техн. наук, проф. К. С. Васюта, Харківський національний університет Повітряних Сил імені Івана Кожедуба, Харків Received (Надійшла) 28.03.2018 Accepted for publication (Прийнята до друку) 16.05.2018

\section{Использование системы мультилатерации для увеличения качества ведения радиолокационного контроля воздушного пространства}

А. В. Федоров, В. В. Чалий, В. П. Финаев

Предметом изучения в статье является система мультилатерации (MLAT) и ее взаимодействие с существующими средствами радиолокации при ведении радиолокационного контроля (РЛК) воздушного пространства. Целью является анализ возможностей использования системы MLAT для повышения эффективности РЛК воздушного пространства. Задачи: анализ основных тенденций развития средств воздушного нападения, анализ известных организационных и технических путей повышения эффективности ведения РЛК малозаметных и малоразмерных воздушных объектов (ВО), определение направлений сочетание возможностей системы MLAT и информации от существующих радиолокационных средств, анализ возможности получения информации от системы MLAT в радиотехнических подразделениях, анализ особенностей и ограничений на использование информации от системы MLAT. Используемыми методами являются: методы определения координат ВО, разностно-дальномерный метод, методы пассивной радиолокации, методы определения координат ВО с использованием информации спутниковых навигационных систем. Получены следующие результаты. Установлено, что система MLAT является системой независимого кооперативного наблюдения, в основе работы системы MLAT положен известный дальномерный метод определения координат BО, минимальное количество пунктов приема равно трем, получено выражение для линейной погрешности разностно-дальномерного метода в системе MLAT, установлено, что в качестве приемников в системе MLAT возможно использование транспондеров системы ADS-B, приведены несколько вариантов решения задачи по выявлению потенциально опасных ВО, желающих быть незамеченными, или осуществляют "мимикрию". Выводы. Научная новизна полученных результатов заключается в следующем: повышение точности определения координат ВО и качества РЛК воздушного пространства путем сочетания возможностей системы MLAT и информации от существующих радиолокационных средств; установлено, что использование системы MLAT существенно повысит точность сопровождения ВО; намечены пути оптимизации геометрической построения приемников системы MLAT на позициях радиотехнических подразделений и разработки метода совместной обработки радиолокационной информации и информации от системы MLAT при РЛК воздушного пространства.

Ключевы е слов : радиолокационная станция, мультилатерация, MLAT, источник информации, воздушная обстановка, зависимое наблюдение, независимое наблюдение, воздушное пространство, контроль воздушного пространства, координаты.

The multilatery system use for increasing the quality of radar control of the air space A. Fedorov, V. Chalyi, V. Finaev

The subject matter of the article is the multilateration system (MLAT) and interaction this system with modern radar facilities during radar control (RC) of airspace. The goal is to analyze the possibilities of the MLAT system use to improve the efficiency of the RC airspace. The tasks to analysis of the main trends in the development means of air attack, analysis of known organizational and technical ways to improve the efficiency of the RC airspace of low-visibility and small air objects, determination of directions for combining the capabilities of the MLAT system and information from radar equipment, analysis of the possibility of obtaining information from the MLAT system in radio departments, analysis of features and restrictions of using information from the MLAT system. The methods used are: methods of determining coordinates of air objects, the distance-range method, the passive radar methods, methods of determining coordinates of air objects using the information from satellite navigation systems. The following results were obtained. It is identified that the MLAT system is an independent co-operative observation system, the MLAT system is basis of the difference-distance-finding method for determining the coordinates of air objects, the minimum number of receiving points is equal to three, an expression for the linear error of the difference-distance-finding method in the MLAT system is established, it is established that the receivers in the MLAT system it is possible to use transponders ADS-B system, there are several variants of the decision to provide for detection of potentially dangerous air objects which wish to be unnoticed, or carry out "mimicry". Conclusions. The scientific novelty of the results obtained is as follows: to increase the accuracy of the determination of the coordinates of the air objects and the quality of RC of the airspace by combining the capabilities of the MLAT system and the information from the existing radar equipment; found that the MLAT system will use significantly increase the accuracy of air objects tracking; the ways of optimization of geometric construction of receivers of the MLAT system at the positions of the radio units and the development of method for the joint processing of radar information and information from the MLAT system at the RC of the airspace were determined.

Keywords: radars, control point, MLAT, information source, air situation, dependent observation, independent observation, airspace, airspace control, coordinates. 